\title{
Hoteliers and Guests' Perception on Factors Determining Pricing and Service Acceptability in Selected Hotels in Kwara State
}

\author{
Dr Adediran Olabanji Jamiu ${ }^{1^{*}}$, Alabi Risikat Abimbola ${ }^{2}$ \\ ${ }^{1}$ College of Humanities, Management and Social Sciences; Kwara State University, Nigeria \\ ${ }^{2}$ Department of Hospitality Management, Kwara State Polytechnic, Ilorin, Nigeria
}

*Corresponding Author: Dr Adediran Olabanji Jamiu, College of Humanities, Management and Social Sciences; Kwara State University, Nigeria

\begin{abstract}
Changing the price of a product/service in relation to competitor's prices has a major influence on the marketing strategy because it affects the demand for a product and hence the sales. The purpose of this study was to examine hoteliers and guests perception of factors determining the pricing of hotel services and guests' satisfaction of services received against prices paid. Given the key role of pricing in determining customers purchasing decision plus the lack of studies on determinants of pricing of hotel services at the local level, this empirical study was undertaken. Structured questionnaires were designed after consulting with past studies and exploration of opinions of non-randomly selected guests and hoteliers. Thereafter, data was collected from 357 guests - randomly selected and 41 hoteliers from thirteen non-randomly selected hotels. Results of the analysed data show that hoteliers' ranked hotel location (4.61), cost of raw material (4.51), hotel rating (4.49), quality of in-room facilities (4.29) and quality of service attributes (4.20) as the five foremost prices determinants. Whereas, hotel location (4.60), hotel rating (4.50), the season of the year (4.45), quality of service rendered (4.40), and government levies (4.39) are the topmost factors perceived by hotel guests as pricing determinant. Results of hypotheses tested at 0.05 level of significant show that hoteliers' perception of factors that determine pricing was significantly influenced by gender but wasn't influenced by years of working. Guests' perception of factors determining the pricing of services was significantly influenced by gender and income, and guests' acceptability of the quality of service received in relation to prices paid for those services were satisfactory. Finally, there was a significant difference in hoteliers and guests' perception of factors determining the pricing of services. The study recommended that hoteliers should incorporate guests' perceptions into their decisions when fixing charges for their various services.
\end{abstract}

Keywords: pricing policy, pricing triangle, hoteliers, hotel services, ancillary services, competitors, demand and supply

\section{INTRODUCTION}

As global tourists' arrival continues to increase year-on-year, the consequential impacts are largely felt by the hotel industry is an appendage of the tourism industry that is saddled with the task of accommodation provision for tourists/visitors. Expectedly, the more the number of tourists or visitors that are naturally out of their usual environment for more than twenty-four hours, there is certainly an increasing demand in the number of accommodation services for this reason. This is because; accommodation provides a base where a traveler can engage in the process of staying at a destination. Accommodation is a centre of focus when hosting guests. It is an important element that travellers considered when planning their trip and it remains a fundamental element of travel and tourism. Irrespective of travelers' class, types and demographic variables, travelers would naturally need accommodation, given that they will be outside their usual environment for at least one night. The hotel as a component of the hospitality industry is directly responsible for the provision of accommodation and food (Adesina \& Chinonso, 2015) to visitors. Jones (2002) affirms as the author described the provision of lodging facility as the vertebrae of the hospitality industry. Although, the key service that travelers desire in the hotel is accommodation, however, additional services being offered is what clearly distinguishes the hotel from other sleeping facility provider s such as camps, hostels, inns, Air BnB's and so on. 
As the hotel industry continues to be one of the fastest-growing service industries in the world (Tefera \& Govender, 2017), likewise, the hotel industry in Nigeria is slowly but steadily enjoying economic growth and creating thousands of jobs. Recognising that the service requirements of the hotel customers vary, just as there are diverse reasons motivating guests' hotel selection (Adediran \& Sule, 2019), hotel guests make their choices based factors that include hotels ability to satisfy their desires including the perception of quality of service, pricing, reward and other marketing and sales offering variables. As hotels in Nigeria and the study area continue to benefits from the global prosperity the hospitality industry has recorded, more attention is required to ensure that local hotels deliver quality and acceptable service which could lead to sustainable patronage from guests who are the pillars behind the success the hotel industry had so far realised. More so, as hotel patronage continues to improve in Nigeria, hoteliers need to adopt and use a successful market mix of the right service, to sell at the right price, in the right place and using the most suitable price-fixing strategies to influence guests' decision and leading to profitable dealings.

On the issue of pricing, it has been observed that pricing of hotel services in the study area vary. Even for similar services, hotels within the same vicinity in the study area are charging varying prices. It was further noticed that two differently branded hotels with annexes within the study area charge different prices for the same services. This shows clearly that some factors are certainly determining charges of hotel services. While acknowledging foreign studies that had examined factors influencing the pricing of hotel rooms (Ting Hung et al., 2010; El-Nemr, Canel-Depitre and Taghipour (2017), there is a dearth of research on this issue locally. More so, the majority of the studies that are available both locally and internationally were based on secondary data and mostly addressed pricing related issue majorly on the room rate. Meaning, aside from room rate, price determinants in relation to other hotel services such as food and beverages, dry-cleaning, gym and exercise facility (wellness), pick-up and drop-off, and so on were not addressed.

While foreign hotels and guests have been extensively researched on this topic, same cannot be said of hoteliers and guests in Nigeria and in the study area. In reality, recommendations from foreign studies may not be entirely acceptable and implementable for local circumstances. In addition, differences in respondents' (hoteliers and guests) socio-demographic characteristics will most likely sway the outcome of this study. This is because of respondents' perception of the same issue from two different regions may differ and consequently affect other variables differently. Finally, the growing patronage for hotels services -the hotel industry's contribution to the Nigeria economy is an attestation that academic studies aimed at examining local situations on this matter is justifiable. Therefore, this current study is noteworthy given that it will attempt to fill up our knowledge gap on what determines the pricing of hotel services in the study area, the variations in the pricing of some services being offered in hotels, especially hotels within the same geographical location. To achieve an empirical study on perceptions of guests and hoteliers on factors determining pricing of hotel services in Kwara state, the following objectives have been set: (i) to conduct guests and hoteliers socio-demographic characteristics profiling (ii) to evaluate guests' and hoteliers perception of factors determining pricing of hotel services (iii) to analyse guests' acceptability of the quality of service received in relation to prices paid for service (iv) to examine if there is a significant difference between the perception of hoteliers and guests on factors determining the pricing of hotel service, and (v) to determine if guests and hoteliers socio-demographic characteristics influence their perception of the pricing of hotel services.

Recommendations from this current study will be a tailor-made (empirically explored -not based on observation or an adaptation) for hoteliers and guests' in the study area and similar environs as both hoteliers and guests'. It will be a vital piece of information as hotel guests will be informed about the knowledge and understanding of pricing as a strategic tool used in the management of demand and supply of products and services while informing hoteliers of gusts' perception of quality of service received in comparison with prices paid.

\section{THEORETICAL FrAMEWORK}

This study adopted the theory of Pricing Triangle by Wilson et al. (2008). According to the theory of pricing, when a service provider wants to establish a market-oriented pricing policy, prices would be based on the three Cs which are (i) the cost of creating the service, (ii) customers' perception of value 
and, (iii) competitors offering. Previous to Wilson's study, Kotler had in 1998 put forward a pricing model that was aimed at helping companies to position their products/services comparatively to competitors, and, as perceived by the market whilst considering their pricing strategy. Interestingly, Kotler (1998) shared a similar view with Wilson's as the author submitted that products/services pricing is directly proportional to customers' perceived quality of either a product or service. An intriguing aspect of pricing is that buyers are likely to use price as a gauge for service costs and service quality. That is, consumers usually take price as a key determinant of service quality expected of purchased services. Both Kotler and Wilson's studies remained a point of reference for old and latest studies on pricing, especially on the association between guests'/customers' perception of the connection between price and quality, this study equally conducted a crosschecking exercise on guests' perception of prices paid and the quality of services received for the selected hotel services in the study area.

Further on the relationship between pricing and factors determining it, Wilson et al. (2008) on page 434 stated that the direct and indirect costs incurred in the provision of services, analyses of competitors' price, customers perception of value, company's expected profit margin and customers demand for services are vital elements that determine pricing. The aforementioned elements were found to be the basis that formed discussion on most of the reviewed literature and has been adopted for this study. In view of the above, this current study developed research questionnaires that separately focused on guests and management views in relation to factors determining the pricing of hotel services as prescribed by the pricing and other variables that were explored through literature and interview with selected hoteliers and guests.

\section{Concept of Pricing of Products and Services}

Price is the actual amount of money that customers have to pay to acquire a particular product or service. While describing pricing in the context of the hotel industry, Lumsdon (1997) illustrated that price is the amount of money that guests are willing to pay for the exchange of benefits of having or using hotel services. Pricing is the amount of money customers exchange for an assortment of products and services provided by sellers or, in this case, accommodation establishment (Monroe, 2002). There are different perceptions by stakeholders on what price means. This perhaps explains why Keller (1997) stated that the traveler and accommodation establishment attach different meaning to price. The author stated that hotel guests or visitors will view price as acceptable if the value equals the amount of money that is being paid for the product/service. However, hoteliers perceive that price relates directly to income and profitability, and, price determines the profits margin a company makes (Rogerson, 2013). Price is the value attached to a product; it is the single element of the marketing mix that makes a profit for the organisation.

Changing the price of a product in relation to competitor's prices has a major influence on the marketing strategy because it affects the demand for a product and hence the sales. When stakeholders are comparing prices, Cant (2003) highlighted the need for the following considerations (i) similarity of the product/service (ii) the unique features that warrant a higher price, and (iii) consumers' perception of value. Cant's view reiterated the need for pricing to complement the other elements of the marketing mix, especially in relation to demand. According to Rogerson (2013), the demand for a product/service will not be high if the prices are unattractive (too high or too low) in comparison to competitors' prices, in spite of the attractiveness and the packaging. Thus, the price charged by the seller ought to match the product (Markgraf, 2015). Some of the attributes of price such as discounts, allowances, payment periods and credit terms should be considered well in advance when organisation are putting a price strategy in place. Also, organisations must know the value attached to their products/services because in most cases both potential and current customers will perceive the quality of a product/service as a basis for the price(s) fixed (Wilson et al. 2008).

Price is an essential management tool that relates to the realisation of business objectives. It is a strategic tool concerned with the management of demand and supply of products and services (Haarhoff, 2007). According to Davashish (2011), the price strategy includes the real price, discounted price as well as volume discounts that the organisation charges. Shoemaker (2003) while reviewing the trend of pricing of services in the hospitality industry identified four phases of pricing in the hotel business as follow (i) rates vary by season (ii) yield management system such as revenue 
per available room (iii) revenue management based on available customers, and (iv) value pricing (based on value received and not cods to produce). The author further put forward that pricing will reach a phase when the customer is completely incorporated in the pricing decision. Although, Myers (2001) stated that customers would have a different perception of the products depending on the price. Therefore, for customers, pricing is a difficult task given that a high price may cause negative feelings about products/services; likewise, a low price can be misleading on other products and services as customers may likely attribute low pricing to inferior quality.

There are different types of pricing systems which a hotel usually adopts. First is the demand-oriented pricing actually considers the demand for the product before the price for the product is fixed. Examples are discrimination pricing, backward pricing, psychological pricing, market penetration pricing and skimming price. Second is the cost-oriented pricing, this considers the cost of making or purchasing the product as an important element when fixing prices. Under this pricing system, additional money is added to the cost of the product to make the selling price. An example includes cost-plus pricing and rate return (Cooper et al. 2008). Lewis and Shoemaker (1997) postulated that a technique known as Price Sensitivity Measurement (PSM) can be used to determine how customers' perception of value is affected by the interaction of price and quality. Price-value they said has become a common expression for a relationship that goes beyond the manifested monetary price of an item or service. 'In spite of the continued campaign for the consumer participation in service pricing, Hinterhubber (2008) identified five main obstacles to the implementation of value-based pricing strategies: deficits in value assessment; deficits in value communication; lack of effective market segmentation; deficits in sales force management; lack of support from senior management. Literature, however, tends more towards incorporating customers' value perceptions into the pricing of hotel accommodations.

One additional factor put forward by Varini et al. (2003) the guests' willingness to pay for services. The author emphasised that this is not enough for profit optimisation, but a primary indicator when deciding service pricing. Notwithstanding the several importance of pricing, the chief importance and reason most establishments engage in pricing strategy is to generate revenues (Potter, 2000; and O’Connor, 2003; Avlonitis \& Indounas, 2006).

\subsection{Factors Determining Hotel Services Pricing}

The provision of basic infrastructure such as the quality and location of lodging facilities to travelers can influence the attractiveness of the destination; consequently, can influence pricing (Ruta \& Pedrosa, 2005). Although there is no specific pricing strategy that is perfect for any hotel, for this reason, a hotel must consider the pricing strategy, or strategies that work best for its particular brand and one that could best deliver their objectives. According to Smith and Woodside (2009), there is nothing such as "one strategy fits all in pricing strategy for all brands, more so, setting specific price points requires continuing deliberate management responses to dynamic market circumstances". Perhaps, this explains one standpoint as to why prices charged by hotels for similar services vary. Pricing of hotel rooms and other services are influential to guests' hotel selection (Lockyer, 2005; Adediran \& Sule, 2019). Although, there are many factors driving hotel pricing such as occupancy rate (number of occupied rental rooms at a given time, compared to the total number of available rental rooms at a given time), especially as unsold rooms achieve nothing, therefore, pricing of hotel rooms to maximise occupancy can often be a better approach than pricing rooms to maximise profit on them individually. In a highly competitive location, it is sometimes necessary to entice guests with lower rates. At least then you have the guests and your competitors don't. One can then find ways to gain more revenue from the guests through other services offered at the hotel. This aligns with Koc (2006), the author explains that owners/managers of accommodation establishments have three main goals; first, to be profitable; second, to be competitive; and third, to sustain the first and second goals. Therefore, pricing can be influenced by the diversity of managers' perceptions of prices (Cassidy \& Guilding, 2007). This further explains why every hotel has a unique room pricing considerations, which depends on several factors such as location, size of the hotel, market demographics, level of competition and types of services offered amongst other factors.

The quality of services such as product quality, food preparation and service, staff attentiveness and professional conduct, hygiene, safety and other variables that translate to a quality experience for 
guests on pricing has also been recognised as influential to pricing. On this, Haarhoof (2007) stated that the quality of a key success factor in managing accommodation establishments. Also, Wilson et al. (2008) liken customers' expectation of the quality of services to pricing. In view of the aforementioned, hotel management needs to focus on achieving and monitoring the quality of service offered given that getting this right will contribute a positive word-of-mouth recommendation. Other factors that are relevant to hotel pricing include (i) the hotel image which is largely influenced by word-of-mouth experience from previous visits; publicity and the marketing campaign (Bolton \& Thompson, 2004), (ii) costs incurred to develop the facilities/putting the services in place (overhead cost). According to Slabbert and Saayman (2003), the matter of overhead-cost should be taken into consideration when determining prices; however, they found that in most cases managers and entrepreneurs do not take these aspects into account.

An additional factor that determines the pricing of hotel services is the environmental qualities, which include aspects such as the natural surroundings, location, climate, quality of the air and water, whether the operation is environmentally friendly, the remoteness of the facility, and variety of attractions around the location where a hotel is situated. Dwyer et al (2004); Cassidy and Guilding (2007) all indicated that the natural environment as well as climate conditions are important attributes of a destination and are significant when the prices of products/services are being decided. When establishments are located in a popular area or destination, the entrepreneur or manager has the advantage to ask a higher price. These results also show that managers could take guests growing environmental concerns into consideration when determining the price. It also correlates with findings by De Keyser and Vanhove (1994) and Gomezelj and Mehalic (2008) that the availability and the quality of available facilities also dictate price-fixing.

Also, the availability of tourists' facilities within the hotel is another factor that contributes to pricing. According to Mangion et al. (2005), tourist facilities are those elements in tourist product/service that do not necessarily provide the motivation for tourist flow, but the absence of which may discourage guests from traveling to enjoy the attraction and accommodation facility. Gomezelj and Mihalic (2008) stated that hotel amenities such as casino, disco, tennis court, children's facilities, recreation facilities are important in determining the price charged by a hotel. This implies that there is a great advantage for a hotel with a wide variety of amenities that caters for more markets, the type that would naturally attract more than a particular class of visitors and subsequently positioned a hotel for wider patronage and make a hotel suitable for broader market demand.

Further on hotel service pricing, Collins and Parsa (2006) identified more factors affecting pricing are hotels rating, management type, location, size and amenities. More so, the frequency and the availability of services based on demand and supply are critical for pricing since these aspects differ from industry to industry, and also from destination to destination. However, the demands for and supply of products and services remain the two most important forces that decide price (Saayman, 2006). On location as a factor influencing price, Cassidy and Guilding (2007), described this to include the distance from an airport, distance from a beach and the quality of the beach. Just as location is a crucial factor determining guests' hotel selection choice, the same location dictates the value paid either for rental or outright purchase of the space which hotels are built and hence a determinant of charges for services rendered.

\section{RESEARCH METHODOLOGY}

This empirical study investigated hoteliers and guests perception of factors determining the pricing of selected hotel services with both exploratory (qualitative) and descriptive (quantitative) approach. The dearth of erstwhile studies on determinants of ancillary hotel service(s) aside room-rate necessitated the adoption of the exploratory approach. Ultimately, useful information that assisted in questionnaire development was gathered from stakeholders (hoteliers and guests). Figure 1 depicts the flow of data collection adopted for this study. When there is a lack or absence of information, exploring useful information from experts/stakeholders is accepted in research (Neuman, 2011) Also, this action aligns with Middleton (2019) that experts can be drafted in, to improve the quality of a research instrument before it is administered. Jennings (2010) acknowledges that Delphi technique -as an approach used when a researcher needs information from particular people who are experts/stakeholders on the issue 
being researched. Also, given the uniqueness of the issue being investigated (hoteliers and guests perception of factors determining prices of selected hotel services); the inputs of selected hoteliers and guests' were sought for the development of research questionnaires. Therefore, twenty guests and five hoteliers were purposely selected independently for relevant queries that were used in questionnaire development. Next is a brief description of the study area, the study population, sample size and sampling technique and questionnaire design and administration. This aligns with Creswell (2014) that the discussion on research methodology should articulate what data is collected, from whom, why and how the data were analysed.

The selected study area in Kwara State is Ilorin. This state was established in 1967 and located within the North Central geopolitical zone. Kwara State comprises sixteen local governments, of these; Ilorin has three local governments which are Ilorin West, Ilorin South and Ilorin East. The three local governments in Ilorin accounted for 30\% of the entire Kwara state population which is projected to reach 3,518,771 (Babatunde, Iyanda \& Mayowa, 2014). That is to say, the population of citizens and residents of Ilorin is currently more than one million. As the state capital, Ilorin houses the most number of institutions Kwara state and this makes the majority of travelers to Kwara state to stop by or have one thing or the other to do in Ilorin. For instance, Ilorin houses Kwara state secretariat, Kwara state Internal Revenue Service (KWIRS), Ministry of Finance, Kwara state Court of Appeal, one of the leading pharmaceutical company in the country, offices of numerous cooperate businesses, state headquarters of banks and residential buildings. As observed, the three Ilorin local governments are the most resided and most visited by the three million Kwara State residents and thousands of interstate travelers respectively. Similarly, Ilorin boasts of many hotels for visitors lodging and entertainment joints, food-service outlets, the University of Ilorin and couple of leading tertiary institution in Nigeria. All the aforementioned make Ilorin one of the fastest-growing state capitals that are receiving large visitor arrivals in Nigeria. On the selection choice of Ilorin for this study, Ilorin houses the largest percentage and the best among hotels in Kwara state. The aforementioned reasons together with the convenience of data collection make the three Ilorin local governments the choice that was selected as the study area for this study.

\subsection{Population, Sampling Sample Size and Sample Distribution}

The stakeholders whose opinions were sought in this study are hotel owners/management (hoteliers) and hotel guests. These two are the most affected when pricing related matter is being decided. Since Nassar, Yahaya and Shorin (2015) reported in their study that there are fifty-five hotels in Ilorin Metropolis; four more hotels have been constructed, bringing the number of hotels in the study area to fifty-nine. Of the fifty-nine hotels, nineteen hotels were selected via non-random sampling (purposive sampling technique) based on the homogeneity of service offering. That is, the selected hotels all have in common the hotel services that were examined. Other criteria used in hotel selection include the location, convenience and star rating. The selected hotels were officially contacted as permission to use their top managers/decision-makers and guests for this study were sought. However, sixteen out of nineteen hotels granted the request on conditions that strict compliance with confidentiality and concealment of their identity be observed. Of the sixteen hotels that agreed, three were further considered for the pilot study and the remaining thirteen hotels were used for the actual study. Below is Table 1 showing the sample distribution, the questionnaire administered and retrieved from both guests and selected management staff.

According to Table 1, a total of 43 hoteliers (comprising of top management staff and a few hotel owners) were identified and considered suitable for this study, hence 43 is the population herewith. Out of this (43) questionnaire were administered to 42 and this yielded 41 responses. On guests' population, given that the data collection exercise was done on a weekend, that is Friday, Saturday and Sunday, the population size of this study comprises all the guests that lodged at the selected hotels on a weekend basis. There is no definite figure regarding guests patronage, it varies. For this reason, the information on the lodging capacity (occupancy) for the last three weekends in each of the thirteen hotels was requested, received and calculated and adopted. From this, a total of 557 guests/lodgers was realised as the average total population of guests and was adopted as the working population. Ideally, 230 is an adequate sample size on a confidence level of $95 \%$ and a marginal error of $5 \%$ for a population of 557 (Jennings (2010). However, for two reasons this study sampled 385 guests nonrandomly. Firstly, there was an opportunity to get more than 230 respondents because of the support 
received from the management of the selected hotels and, secondly, we decided to be rational in administering the questionnaires for the various hotels so as to ensure a reasonable representation of the individual population of guests were sampled. Table 1 shows the breakdown of the population for top management staff and guests, and, sample sizes for each hotel. In real-time, a total of 405 copies of respondents-completed questionnaire were administered rationally out of which 357 which implies $88 \%$ response rate was retrieved.

Table1. Respondents' Population, Questionnaire Administered and Collected from each hotel

\begin{tabular}{|l|l|l|l|l|l|l|}
\hline S/N & Hotels & $\begin{array}{l}\text { Average Guests } \\
\text { Occupancy For } \\
\text { Previous } \\
\text { Weekends }\end{array}$ & $\begin{array}{l}\text { Number of } \\
\text { Questionnaire } \\
\text { Administered } \\
\text { for Guests }\end{array}$ & $\begin{array}{l}\text { Number Of } \\
\text { Questionnaire } \\
\text { Retrieved from } \\
\text { Guests }\end{array}$ & $\begin{array}{l}\text { Number of } \\
\text { Questionnaire } \\
\text { administered } \\
\text { for Managers }\end{array}$ & $\begin{array}{l}\text { Number } \\
\text { Questionnaire } \\
\text { Retrieved } \\
\text { Managers }\end{array}$ \\
\hline 1 & Hotel A & 42 & 27 & 24 & 3 & 3 \\
\hline 2 & Hotel B & 33 & 25 & 21 & 4 & 3 \\
\hline 3 & Hotel C & 52 & 40 & 36 & 5 & 5 \\
\hline 4 & Hotel D & 37 & 31 & 30 & 2 & 2 \\
\hline 5 & Hotel E & 31 & 25 & 25 & 2 & 2 \\
\hline 6 & Hotel F & 37 & 28 & 22 & 2 & 2 \\
\hline 7 & Hotel G & 59 & 44 & 35 & 3 & 3 \\
\hline 8 & Hotel H & 61 & 53 & 51 & 5 & 5 \\
\hline 9 & Hotel I & 39 & 29 & 24 & 3 & 3 \\
\hline 10 & Hotel J & 28 & 20 & 19 & 3 & 3 \\
\hline 11 & Hotel K & 41 & 35 & 31 & 4 & 4 \\
\hline 12 & Hotel L & 34 & 29 & 23 & 4 & 4 \\
\hline 13 & Hotel M & 23 & 19 & 16 & 2 & 2 \\
\hline TOTAL & $\mathbf{5 5 7}$ & $\mathbf{4 0 5}$ & $\mathbf{3 5 7}$ & $\mathbf{4 2}$ \\
\hline
\end{tabular}

\subsection{Questionnaire Development}

This study employed two structured questionnaires (one for the guests and another one for the hoteliers) designed on a five-point Likert-scale where $1=$ strongly disagree, $2=$ disagree, $3=$ undecided, 4 - agree, and, 5 = strongly agree. The two questionnaires are technically different in terms of content and sections contained. The guests' questionnaire comprised three parts; the first part sought for the respondents' socio-demographic demographic information such as age, gender, level of income, educational qualification. The second section examined guests' perception of factors determining the pricing of selected services in hotels and the third part was used to examine their perception regarding the quality of service received in relationship to prices paid for those services in hotels. The questionnaire for the managers comprise of two parts, the first part requires the managers to fill in their demographic data while the second part was to examine managers' perception of factors determining the pricing of selected services in their hotels. Queries contained in both questionnaires are different as they represented both stakeholders point of view. The two questionnaires were subjected to a content validity exercise. Daramola (2004) describes the validity of a research instrument as determining the extent to which a questionnaire measures a good sample of the variables it intends to measure. Thereafter, a pilot study was conducted with three hotels and a total number of 51 guests-respondents and 8 managers-respondents. With a reliability coefficient score of 0.72 , the questionnaire was adopted and this sets the motion for the actual data collection exercise.

\subsection{Data Collection}

The completion of the pilot study paves the way for the actual data collection as questionnaires were administered via non-random sampling to available guests at the selected hotels based on the willingness to take the survey. Likewise, questionnaires were physically administered to selected top management staff at selected hotels using 'drop and pick later' approach. A total of 41 completed questionnaires were received for managers while 357 were received for guests.

\subsection{Findings}

\subsubsection{Hoteliers' Socio-demographic Characteristics}

In the accomplishment of objective 1 of this study, hoteliers' and guest's socio-demographic characteristics were analysed in Tables 2 and 3 below. 
Hoteliers and Guests' Perception on Factors Determining Pricing and Service Acceptability in Selected Hotels in Kwara State

Table2. Percentage Distributions of Managers' Socioeconomic Profiles

\begin{tabular}{|l|l|l|l|l|}
\hline $\mathbf{N}$ & Variables & & Frequency & Percentage \% \\
\hline 1. & Gender & Male & 24 & 58.5 \\
\hline & & Female & 17 & 41.5 \\
\hline & & Total & $\mathbf{4 1}$ & $\mathbf{1 0 0 . 0}$ \\
\hline 2. & Age (In years) & 20 \& below & 2 & 4.9 \\
\hline & & $21-25$ & 9 & 22.0 \\
\hline & & $26-30$ & 5 & 12.2 \\
\hline & & $31-35$ & 8 & 19.5 \\
\hline & & $36-40$ & 6 & 14.6 \\
\hline & & 40 \& above & 11 & 26.8 \\
\hline & & Total & $\mathbf{4 1}$ & $\mathbf{1 0 0 . 0}$ \\
\hline 3. & Education & Vocational Education & 0 & 0.0 \\
\hline & & Primary & 0 & 0.0 \\
\hline & & SSCE & 4 & 9.8 \\
\hline & & NCE/OND & 9 & 22.0 \\
\hline & & B.Sc/HND & 15 & 36.6 \\
\hline & & M.Sc & 13 & 31.7 \\
\hline & & PhD & 0 & 0.0 \\
\hline & & Total & $\mathbf{4 1}$ & $\mathbf{1 0 0 . 0}$ \\
\hline 4 & Working experience & 1 \& below & 2 & 4.9 \\
\hline & & $2-3$ & 3 & 7.3 \\
\hline & & $4-5$ & 2 & 4.9 \\
\hline & & $6-7$ & 24 & 58.5 \\
\hline & & 8 \& above & 10 & 24.4 \\
\hline & & Total & $\mathbf{4 1}$ & \\
\hline
\end{tabular}

Table 2 presents the hoteliers socio-demographic profile. The table shows that out of the 41 respondents, $24(58.5 \%)$ were male; while $17(41.5 \%)$ were female. The age of the respondents indicated in years shows that $2(4.9 \%)$ were 20 and below; $9(22.0 \%)$ were between $21-25 ; 5(12.2 \%)$ were between 26-30; 8 (19.5\%) were between 31-35, 6 (14.6\%) were between 36-40; while 11 $(26.8 \%)$ of the respondents were 40 years and above. The educational qualification of the respondents revealed that none $(0.0 \%)$ of them has vocational education, primary and $\mathrm{Ph} . \mathrm{D}$ qualifications, 4 (9.8\%) have SSCE certificate, 9 (22.0\%) have NCE/OND certificates, 15 (36.6\%) were B.Sc /HND; while holders, $13(31.7 \%)$ were Master Degree certificate holders. Based on working experience, 2 $(4.9 \%)$ of the respondents have 1 year and below working experience, 3 (7.3\%) have between 2-3 years experience, 2 (4.9\%) have been working for 4 to 5 years, 24 (58.5\%) have had between 6-7 years working experience; while $10(24.4 \%)$ have spent 8 years and above as hotel manager.

Table3. Percentage Distributions of Guests' Socioeconomic Profiles

\begin{tabular}{|l|l|l|l|l|}
\hline $\mathbf{N}$ & Variables & & Frequency & Percentage \% \\
\hline 1. & Gender & Male & 208 & 58.3 \\
\hline & & Female & 149 & 41.7 \\
\hline & & Total & $\mathbf{3 5 7}$ & $\mathbf{1 0 0 . 0}$ \\
\hline 2. & Age (In years) & 20 \& below & 42 & 11.8 \\
\hline & & $21-25$ & 104 & 29.1 \\
\hline & & $26-30$ & 125 & 35.0 \\
\hline & & $31-35$ & 15 & 4.2 \\
\hline & & $36-40$ & 39 & 10.9 \\
\hline & $40 \&$ above & 32 & 9.0 \\
\hline 3. & Total & $\mathbf{3 5 7}$ & $\mathbf{1 0 0 . 0}$ \\
\hline & & Single & 149 & 41.7 \\
\hline & & Engaged & 67 & 18.8 \\
\hline & & Married & 116 & 32.5 \\
\hline & Marital Status & Divorced & 17 & 4.8 \\
\hline & & Widowed & 6 & 1.7 \\
\hline & & Separated & 2 & 0.6 \\
\hline & & Total & $\mathbf{3 5 7}$ & $\mathbf{1 0 0 . 0}$ \\
\hline & & &
\end{tabular}


Hoteliers and Guests' Perception on Factors Determining Pricing and Service Acceptability in Selected Hotels in Kwara State

\begin{tabular}{|l|l|l|l|l|}
\hline 4 & Education & Non-formal & 11 & 3.1 \\
\hline & & Primary & 14 & 3.9 \\
\hline & & O'Level & 30 & 8.4 \\
\hline & NCE/OND & 109 & 30.5 \\
\hline & & HND/B.Sc & 125 & 35.0 \\
\hline & M.Sc & 46 & 12.9 \\
\hline & & PhD & 20 & 5.6 \\
\hline & & Others & 2 & 0.6 \\
\hline 5 & & Total & $\mathbf{3 5 7}$ & $\mathbf{1 0 0 . 0}$ \\
\hline & & Employed & 163 & 45.7 \\
\hline & & Unemployed & 73 & 20.4 \\
\hline & & Self-employed & 101 & 28.3 \\
\hline & & Pensioner & 10 & 2.8 \\
\hline & & Other & 10 & 2.8 \\
\hline 6 & & Total & $\mathbf{3 5 7}$ & $\mathbf{1 0 0 . 0}$ \\
\hline & & 50,000 \& below & 148 & 41.5 \\
\hline & & $50,001-75,000$ & 93 & 26.1 \\
\hline & & $75,001-100,000$ & 38 & 10.6 \\
\hline & & $100,001-125,000$ & 22 & 6.2 \\
\hline & & $125,001-150,000$ & 28 & 7.8 \\
\hline & & $150,001-175,000$ & 14 & 3.9 \\
\hline & & $175,001-200,000$ & 6 & 1.7 \\
\hline & & 200,001 \& above & 8 & 2.2 \\
\hline & & Total & $\mathbf{3 5 7}$ & $\mathbf{1 0 0 . 0}$ \\
\hline
\end{tabular}

Table 3 presents the guests' socio-demographic profiles. The table shows that out of the 357 guests who participated in the study, $208(58.3 \%)$ were male; while $149(41.7 \%)$ were female. The age of the respondents indicated that $42(11.8 \%)$ were 20 years and below, $104(29.1 \%)$ were between 21-25 years, $125(35.0 \%)$ were between $26-30$ years, $15(4.2 \%)$ were between $31-35$ years, $39(10.9 \%)$ were between 36-40; while 32 (9.1\%) of the respondents were 40 years and above. The marital status of the respondents revealed that $149(41.7 \%)$ of them were singles, $67(18.8 \%)$ were engaged, $116(32.5 \%)$ were married, $17(4.8 \%)$ were divorced, $6(1.7 \%)$ were widowed; while $2(0.6 \%)$ were of the respondents were from separated home. In terms of education, $11(3.1 \%)$ of the respondents have nonformal education, $14(3.9 \%)$ were primary school certificate holders, $30(8.4 \%)$ have O' Level certificates, $109(30.5 \%)$ were NCE/OND certificate holders, $125(35.0 \%)$ have HND/B.Sc certificates, 46 (12.9\%) were Master Degree holders, 20 (5.6\%) were Ph.D holders; while $2(0.6 \%)$ has other forms of educational qualification. Based on employment status, $163(45.7 \%)$ of the respondents have were employed, 73 (20.4\%) were unemployed, 101 (28.3\%) were self-employed, 10 (2.8\%) were pensioners; while $10(2.8 \%)$ were in other forms of employment status. With regards to the respondents income, $148(41.5 \%)$ earned below 5 years and below, $93(26.1 \%)$ earned between 50,001-75,000, $38(10.6 \%)$ were between 75,001-100,000, $22(6.2 \%)$ earned 100,001-125,000, 28 (7.8\%) earned between 125,001-150,000, 14 (3.9\%) earned between 150,001-175,000, 6 (1.7\%) earned between 175,001-200,000; while 8 (2.2\%) earned 200,001 and above.

\subsubsection{Hoteliers' and Guests Perceptions of Factors Determining Pricing of Hotel Services}

Accomplishing objective two of this study, hoteliers and guests perceptions of factors determining pricing of hotel services is presented in Tables 4 and 5 below.

Table4. Mean and Rank Order of Hoteliers' Perception of Factors Determining Pricing of Services in Selected Hotels

\begin{tabular}{|l|l|l|l|l|}
\hline $\mathbf{N}$ & $\begin{array}{l}\text { The under-listed factors are influential in determining } \\
\text { the prices of services in hotels }\end{array}$ & Mean & SD & Rank \\
\hline 1 & Hotel location & 4.61 & 0.54 & $1^{\text {st }}$ \\
\hline 9 & $\begin{array}{l}\text { Cost of raw materials such as the ingredients for food and } \\
\text { beverage production/cost of equipping in-room facility }\end{array}$ & 4.51 & 0.77 & $2^{\text {nd }}$ \\
\hline 2 & Hotel rating (such as one star, two stars and so on) & 4.49 & 0.59 & $3^{\text {rd }}$ \\
\hline 6 & $\begin{array}{l}\text { Standard/quality of in-rooms facilities (in terms of facilities } \\
\text { available in the rooms such as fridge, TV, AC) }\end{array}$ & 4.29 & 0.84 & $4^{\text {th }}$ \\
\hline 5 & The quality of attributes invested in services rendered & 4.20 & 0.90 & $5^{\text {th }}$ \\
\hline
\end{tabular}


Hoteliers and Guests' Perception on Factors Determining Pricing and Service Acceptability in Selected Hotels in Kwara State

\begin{tabular}{|c|c|c|c|c|}
\hline 12 & $\begin{array}{l}\text { Hotel's reputation/popularity (for instance, hotels with } \\
\text { known name and brand) }\end{array}$ & 4.15 & 0.79 & $6^{\text {th }}$ \\
\hline 11 & Types of hotel (resort, business, transit, chalet) & 4.12 & 0.84 & $7^{\text {th }}$ \\
\hline 3 & $\begin{array}{l}\text { Available amenities in the hotel such as internet service } \\
\text { facilities, sport and recreation facilities) }\end{array}$ & 4.07 & 0.81 & $8^{\text {th }}$ \\
\hline 10 & $\begin{array}{l}\text { Level of competition/availability of alternative (where there } \\
\text { are hotels nearby that are offering the same service for a } \\
\text { lower cost) }\end{array}$ & 4.02 & 0.96 & $8^{\text {th }}$ \\
\hline 7 & Rate/volume of guests' demand for a particular service & 3.98 & 0.96 & $10^{\text {th }}$ \\
\hline 8 & $\begin{array}{l}\text { Seasonality (special period such as Christmas, Easter, Eid- } \\
\text { el celebration, on-peak and off-peak period and so on }\end{array}$ & 3.95 & 1.07 & $11^{\text {th }}$ \\
\hline 4 & $\begin{array}{l}\text { Government levies (such as tax rate, cost of registration and } \\
\text { others) }\end{array}$ & 3.78 & 1.27 & $12^{\text {th }}$ \\
\hline
\end{tabular}

Table 4 presents the mean and rank order of hoteliers' perceptions of factors determining prices of hotel services. The table shows that all the 12 items met the set benchmark of 3.00 (since a fivepoint Likert scale questionnaire was used) for determining the main factors determining charges for services in selected hotels. However, items $1,9,2,6$ and 5 with mean $(\bar{x})$ values of $4.461(\sigma=0.54)$, $4.51(\sigma=0.77), 4.49(\sigma=0.59), 4.29(\sigma=0.84)$ and $4.20(\sigma=0.90)$ preceded others and were ranked 1st, 2nd, 3rd, 4th and 5th respectively. This indicated that the location of hotels, cost of purchasing raw materials such as the ingredients for food and beverage production, hotel rating (such as a star, two stars and so on), the standard of rooms in the hotel (in terms of facilities available in the rooms such as fridge, TV, AC) and quality of services rendered are the managers' perceived factors determining charges of services in selected hotels in the study area. This agrees with Ruta and Pedrosa (2005) who divided the factors that influence pricing from management perception into four qualitatively distinct groups, namely (i) the quality of services and related attributes (ii) location variables, describing the establishment's location regarding major attractions, shopping malls and proximity to entertainment spots (iii) environmental variables, which affect the quality of the area near the accommodation facility, and (iv) infrastructural service and relevant variables. Findings herein also align with Collins and Parsa (2006), authors identified that hotel rating, management type, location, size and amenities as factors determining hotel service pricing.

Table5. Mean and Rank Order of Guests' Perception of Factors Determining Prices of selected Services

\begin{tabular}{|l|l|l|l|l|}
\hline $\mathbf{N}$ & $\begin{array}{l}\text { The under-listed factors are influential in determining the prices of } \\
\text { services in hotels }\end{array}$ & Mean & SD & Rank \\
\hline 1 & $\begin{array}{l}\text { Location of hotel (in terms of appropriateness for guests social status } \\
\text { and other lodging purposes) }\end{array}$ & 4.60 & 0.62 & $1^{\text {st }}$ \\
\hline 2 & Hotel rating (such as one star, two stars and so on) & 4.50 & 0.63 & $2^{\text {nd }}$ \\
\hline 8 & Season of the year & 4.45 & 0.68 & $3^{\text {rd }}$ \\
\hline 5 & Quality of services rendered & 4.40 & 0.72 & $4^{\text {th }}$ \\
\hline 4 & Government levies (such as tax rate, cost of registration and others) & 4.39 & 0.85 & $5^{\text {th }}$ \\
\hline 6 & $\begin{array}{l}\text { Standard/ quality of in-rooms facilities (in terms of facilities available } \\
\text { in the rooms such as fridge, TV, AC) }\end{array}$ & 4.30 & 0.80 & $6^{\text {th }}$ \\
\hline 10 & $\begin{array}{l}\text { Competition in a situation where hotels nearby are offering the same } \\
\text { service for a lower cost }\end{array}$ & 4.29 & 0.92 & $7^{\text {th }}$ \\
\hline 3 & $\begin{array}{l}\text { Available amenities in the hotel such as internet service facilities, sport } \\
\text { and recreation facilities) }\end{array}$ & 4.26 & 0.93 & $8^{\text {th }}$ \\
\hline 12 & $\begin{array}{l}\text { Hotel's reputation/popularity (for instance, hotels with known name } \\
\text { and brand) }\end{array}$ & 4.22 & 0.92 & $9^{\text {th }}$ \\
\hline 11 & Types of hotel (resort, business, transit, chalet) & 4.21 & 0.99 & $9^{\text {th }}$ \\
\hline 9 & $\begin{array}{l}\text { Cost of purchasing raw materials such as the ingredients for food and } \\
\text { beverage production }\end{array}$ & 4.20 & 0.93 & $11^{\text {th }}$ \\
\hline 7 & Rate/volume of guests' demand for a particular service & 4.15 & 1.04 & $12^{\text {th }}$ \\
\hline
\end{tabular}

Table 5 presents the mean and rank order of guests' perceptions of factors determining the pricing of services in selected hotels. The table shows that all the 12 items met the set benchmark of 3.00 for determining the main factors determining the pricing of services in selected hotels. However, items 1 , $2,8,5$ and 4 with mean $(\bar{x})$ values of $4.60(\sigma=0.62), 4.50(\sigma=0.63), 4.45(\sigma=0.68), 4.40(\sigma=0.72)$ and $4.39(\sigma=0.85)$ preceded others and were ranked $1^{\text {st, }} 2^{\text {nd }}, 3^{\text {rd }}, 4^{\text {th }}$ and $5^{\text {th }}$ respectively. This indicated 
Hoteliers and Guests' Perception on Factors Determining Pricing and Service Acceptability in Selected Hotels in Kwara State

that the location of hotel, hotel rating (such as star, two and so on), the season of the year, quality of services rendered and government levies (such as tax rate, cost of registration and others) are the guests' perceived factors determining the pricing of services in hotels in the study area. Two highly ranked factors herein correlate with the findings by Monty and Skidmore (2003), authors found that location, day of the week, and time of year are important determinants of hotel pricing.

\subsubsection{Guests' Satisfaction with the Quality of Service Received Against Prices Charged.}

The third objective was accomplished by the analyses of guests 'satisfaction on the quality of services received against prices paid for these services as presented in Table6.

Table6. Mean and Rank Order of Guests' Acceptability of Quality of Services Received versus Prices Paid for Services in Selected Hotels

\begin{tabular}{|l|l|l|l|l|}
\hline $\mathbf{N}$ & Service acceptable when compared to their prices & Mean & SD & Rank \\
\hline 1 & Room service (food and drinks ordered by guests) & 4.55 & 0.60 & $1^{\text {st }}$ \\
\hline 2 & Accommodation (room rate in view of the in-room facilities & 4.35 & 0.76 & $2^{\text {nd }}$ \\
\hline 6 & Restaurant services (food \& drinks and the service experience) & 4.31 & 0.80 & $3^{\text {rd }}$ \\
\hline 3 & Laundry/dry-cleaning & 4.18 & 0.90 & $4^{\text {th }}$ \\
\hline 7 & Clubs/bars services (food \& drinks) & 4.11 & 0.94 & $5^{\text {th }}$ \\
\hline 4 & Recreation/exercise facilities (such as gym, table tennis) & 4.11 & 1.04 & $5^{\text {th }}$ \\
\hline 5 & Events hall and rental services & 4.05 & 1.03 & $7^{\text {th }}$ \\
\hline 8 & Transport service (car hire) & 3.93 & 1.17 & $8^{\text {th }}$ \\
\hline
\end{tabular}

Table 6 presents the mean and rank order of guests' acceptability of the quality of services received in relation to the prices paid for the services. The table shows that all the 8 items met the set benchmark of 3.00 for determining that the guests' are satisfied with the quality of services received in relation to the prices paid for all the selected services. However, items 1, 2, 6, 3 and 7 with mean $(\overline{\mathrm{x}})$ values of $4.55(\sigma=0.60), 4.35(\sigma=0.76), 4.31(\sigma=0.80), 4.18(\sigma=0.90)$ and $4.11(\sigma=0.94)$ preceded others and were ranked $1^{\text {st }} 2^{\text {nd }}, 3^{\text {rd }}, 4^{\text {th }}$ and $5^{\text {th }}$ respectively. This indicated that, overall, the guests are satisfied with the quality of services received in the hotels in comparison with their prices, particularly on the room service (food and drinks ordered by guests), accommodation, restaurant services (food \& drinks), laundry/dry-cleaning and clubs/bars services (food \& drinks).

\subsubsection{Is There is a Significant Difference Between the Perception of Hoteliers and Guests on Factors Determining the Pricing of Hotel Service?}

To examine if there is a significant difference between the perception of hoteliers and guests on factors determining the pricing of hotel service, consequently responding to the fourth objective of this study, Table 7 presents the findings:

Table7. Independent t-test Result Showing Difference in Managers and Guests' Perception of Factors Determining Pricing of Services in Hotels

\begin{tabular}{|l|l|l|l|l|l|l|l|}
\hline Perception & N & Mean & SD & df & Cal. t & Crit. t & p-value \\
\hline Managers & 41 & 50.17 & 5.44 & & & & \\
\hline & & & & 396 & 1.66 & 1.96 & 0.096 \\
\hline Guests & 357 & 51.96 & 6.61 & & & & \\
\hline
\end{tabular}

Table 7 shows that for a degree of freedom (df) of 396, the calculated t-value of 1.66 is less than the critical t-value of $1.96(p=0.096>0.05)$. This indicates that there is no significant difference in the managers and guests' perception of factors determining the prices of services in selected hotels in Ilorin South LGA; hence, the hypothesis is retained. Therefore, the perceptions of managers and guests' are similar on factors that determine the price of services in hotels.

\subsubsection{Analysis of Guests and Hoteliers Socio-Demographic Characteristics Influence on Their Perception on Pricing of Hotel Services.}

Five null hypotheses were formulated to achieve the fifth objective of this study. These were tested with T-test and Analysis of Variance ANOVA at 0.05 level of significance. Findings on whether guests and hoteliers socio-demographic characteristics influence their perception of pricing of hotel services are presented below: 
Hoteliers and Guests' Perception on Factors Determining Pricing and Service Acceptability in Selected Hotels in Kwara State

$\mathbf{H}_{\mathbf{O 1}}$ : There is no significant difference in the managers' perception of factors determining charges for services in selected hotels in Ilorin on the basis of gender.

Table8. Independent t-test Result Showing Difference in Managers' Perception of Factors Determining Prices for Services in Hotels Based on Gender

\begin{tabular}{|l|l|l|l|l|l|l|l|}
\hline Gender & N & Mean & SD & df & Cal. t & Crit. t & p-value \\
\hline Male & 24 & 51.67 & 4.46 & & & & \\
\hline & & & & 39 & $2.18^{*}$ & 2.02 & 0.035 \\
\hline Female & 17 & 48.06 & 6.09 & & & & \\
\hline
\end{tabular}

* Sig. at $\mathrm{p}<0.05$

Table 8 shows that for degree of freedom (df) of 39, the calculated t-value of 2.18 is greater than the critical t-value of $2.02(\mathrm{p}=0.035<0.05)$. This indicates that there is a significant difference in the managers' perception of factors determining charges for services in selected hotels in Ilorin South LGA on the basis of gender; hence, the hypothesis is rejected. Therefore, the perceptions of male and female hoteliers differ on factors determining charges for services in hotels.

$\mathbf{H}_{\mathbf{O} 2}$ : There is no significant difference in the guests' perception of factors determining prices of services in selected hotels on the basis of gender.

Table9. Independent t-test Result Showing Difference in Guests' Perception of Factors Determining Prices by Gender

\begin{tabular}{|l|l|l|l|l|l|l|l|}
\hline Gender & N & Mean & SD & df & Cal. t & Crit. t & p-value \\
\hline Male & 208 & 52.93 & 5.92 & & & & \\
\hline & & & & 355 & $3.24^{*}$ & 1.96 & 0.001 \\
\hline Female & 149 & 50.66 & 7.27 & & & & \\
\hline
\end{tabular}

* Sig. at $\mathrm{p}<0.05$

Table 9 shows that for a degree of freedom (df) of 355, the calculated t-value of 3.24 is greater than the critical t-value of $1.96(\mathrm{p}=0.001<0.05)$. This indicates that there is a significant difference in the guests' perception of factors determining charges for services in selected hotels services by gender; hence, the hypothesis is rejected. Therefore, the perceptions of male and female guests' were similar on factors determining charges for services in hotels. The mean values for male and female $(52.93 \&$ 50.66) indicates that the opinion of the male guests contribute more to the difference in their perception of the hotels' charges.

$\mathbf{H}_{\mathbf{O} 3}$ : There is no significant difference in the managers' perception of factors determining prices for services in selected hotels on the basis of years of experience.

Table10. ANOVA Result Showing Difference in Hoteliers' Perception of Factors Determining Prices of Services in Hotels Based on Years of Experience

\begin{tabular}{|l|l|l|l|l|l|l|}
\hline Source & Sum of Squares & Df & Mean Square & Cal. F & Crit. F & p-value \\
\hline Between Groups & 246.373 & 5 & 49.275 & 1.84 & 2.49 & .131 \\
\hline Within Groups & 937.432 & 35 & 26.784 & & & \\
\hline Total & 1183.805 & 40 & & & & \\
\hline
\end{tabular}

Table 10 shows that for degrees of freedom (df) of 5 and 35, the calculated F-value of 1.84 is less than the critical F-value of $2.49(\mathrm{p}=0.131>0.05)$. This indicates that there is no significant difference in the managers' perception of factors determining prices for services in selected hotels on the basis of years of experience; hence, the hypothesis is retained. Therefore, the perceptions of the hoteliers were similar on factors determining charges for services in hotels irrespective of their different years of working experiences. This disagrees with Cassidy and Guilding (2007) that pricing can be influenced by the diversity of managers'.

$\mathbf{H}_{\mathbf{O} 4}$ : There is no significant difference in the guests' perception of factors determining charges for services in selected hotels in Ilorin on the basis of income.

Table11a. ANOVA Result Showing Difference in Guests' Perception of Factors Determining Pricing of Hotel Service by Income

\begin{tabular}{|l|l|l|l|l|l|l|}
\hline Source & Sum of Squares & Df & Mean Square & Cal. F & Crit. F & p-value \\
\hline Between Groups & 777.303 & 7 & 111.043 & $2.61^{*}$ & 2.03 & .012 \\
\hline
\end{tabular}


Hoteliers and Guests' Perception on Factors Determining Pricing and Service Acceptability in Selected Hotels in Kwara State

\begin{tabular}{|l|l|l|l|l|l|l|}
\hline Within Groups & 14797.066 & 349 & 42.398 & & & \\
\hline Total & 15574.370 & 356 & & & & \\
\hline
\end{tabular}

* Sig. at $\mathrm{p}<0.05$

Table 11a shows that for degrees of freedom (df) of 7 and 349, the calculated F-value of 2.61 is greater than the critical F-value of $2.03(\mathrm{p}=0.012<0.05)$. This indicates that there is a significant difference in the guests' perception of factors determining prices of services in selected hotels in Ilorin South LGA on the basis of income; hence, the hypothesis is rejected. Therefore, the perceptions of the guests' with varying monthly income were different on factors determining charges for services in hotels. A post-hoc Duncan Multiple Range Test (DMRT) was conducted to show which among the income variables contribute more to the difference observed in Table $11 \mathrm{~b}$.

Table11b. DMRT Showing the Income Group Responsible for the Observed Difference in Guests' Perceptions on Factors that Determine Prices of Services in Hotels

\begin{tabular}{|l|l|l|l|}
\hline Income & $\mathbf{N}$ & Mean & Group \\
\hline $100,001-125,000$ & 22 & 50.27 & 5 \\
\hline $75,001-100,00$ & 38 & 50.29 & 5 \\
\hline $50 \mathrm{k} \&$ below & 148 & 51.34 & 4 \\
\hline $50,001-75,000$ & 93 & 52.39 & 3 \\
\hline $200,001 \&$ above & 8 & 52.50 & 3 \\
\hline $175,001-200,000$ & 6 & 54.00 & 2 \\
\hline $125,001-150,000$ & 28 & 54.29 & 2 \\
\hline $150,001-175,000$ & 14 & 57.00 & 1 \\
\hline
\end{tabular}

Table 11b shows that the mean scores of 54.29 and 54.00; 52.50 and 52.39; and 50.29 and 50.27 slightly different from each other and were classified into groups 2,3 and 5 respectively. The groups 1 and 4 have mean values of 57.00 and 51.34 respectively. However, the mean value of 57.00 in group 1 took precedence over others, followed by groups 2 and 3. In view of this, respondents are greater than that of groups 2 and 3. This implies that the perceptions of respondents with a high level of income $(50,000-200,001 \&$ above) contributed more to the difference observed in table 10 . This suggested that guests with high-income level have more understanding of the factors that influence the prices they pay for hotel services experienced.

Ho5: There is no significant difference between guests' perception of factors determining the pricing of hotel services and quality of service received is related to the prices paid.

Table12. Paired-Sample t-test Result Showing Difference in Guests' Perception of Factors Determining Prices and Quality of Services Received in Hotels

\begin{tabular}{|l|l|l|l|l|l|l|l|}
\hline Perception & $\mathrm{N}$ & Mean & SD & df & Cal. t & Crit. T & p-value \\
\hline Charges & 357 & 51.96 & 6.61 & & & & \\
\hline Quality of Services & 357 & & & 356 & $68.63^{*}$ & 1.96 & 0.000 \\
\hline
\end{tabular}

* Sig. at $\mathrm{p}<0.05$

Table 12 shows that for the degree of freedom (df) of 356, the calculated t-value of 68.63 is greater than the critical $\mathrm{t}$-value of $1.96(\mathrm{p}=0.000<0.05)$. This indicates that there is a significant difference between guests' perception of factors determining prices of services and quality of service received in relation to the prices paid in selected hotels in Ilorin South LGA; hence, the hypothesis is rejected. Therefore, the guests' are different on factors determining charges and quality of service received in relation to the prices paid in selected hotels. The mean values for the services charges factors (51.96) and quality of services (33.58) indicate that the factors guests' consider is a determinant of the quality of service received in hotels. This agrees with the findings by Stevens (2002), Crouch and Ritchie (2009), and Mangion et al. (2005) that the quality service consists of product quality, quality food, hygiene and safety. All four factors contribute to the overall service that guests experience while patronising a hotel it also supports research by Crouch and Ritchie (2009), and Mangion et al. (2005).

\section{CONCLUSION AND RECOMMENDATION}

This study was conducted based on the observed situations where hotels are charging varying prices for the same service and the over-reliance on recommendations from foreign studies on factors 
determining the pricing of hotel service for local guests. This study achieved all it sets out to and the findings from the data collected from hoteliers and guests resulted in the under listed major conclusions that:

- The hoteliers' perceived the following topmost factors as determinants of pricing of services in selected hotels cost of purchasing raw materials such as the ingredients for food and beverage production, hotel rating (such as a star, two stars and so on), the standard of rooms in the hotel (in terms of facilities available in the rooms such as fridge, TV, AC) and quality of services rendered.

- The guests' perceived factors the following topmost factors as determinants of pricing of services in selected hotels as the location of the hotel, hotel rating (such as a star, two stars and so on), the season of the year, quality of services rendered and government levies (such as tax rate, cost of registration and others).

- Overall, the guests' acceptability of the quality of services received in the hotels in comparison with prices paid for those services was impressive.

- There was a significant difference in hoteliers' perception of factors determining the pricing of services by gender.

- There was a significant difference in the guests' perception of factors determining the pricing of services by gender.

- There was no significant difference in the hoteliers' perception of factors determining the pricing of services by years of work experience.

- There was a significant difference in the guests' perception of factors determining the pricing of services by income.

- There was a significant difference in the hoteliers versus guests' perception of factors determining the pricing of services.

- There was a significant difference between guests' perception of factors determining prices of services and quality of service received with the prices paid for these services.

Based on the findings of this study, hoteliers should incorporate guests' perceptions into pricing decisions and should continually uphold price-policy that represents the interest of their guests to promote/enjoy sustainable patronage.

\section{REFERENCES}

[1] Adediran, O.J \& Sule, L.A. (2019). The influence of hotel attributes and travelers' socio- demographic characteristics on hotel selection in Ilorin Metropolis. The international journal of business \& management, 12(7): $139-146$

[2] Adesina, K.I. \& Chinonso, I. (2015). Service delivery and customer satisfaction in hospitality industry: a study of the divine fountain hotels limited. Journal of hospitality and management tourism, 6(1), 1-7.

[3] Avlonitis, G. \& Indounas, K. (2006), "Pricing practices of service organizations", Journal of Services Marketing, 20(5): 346-356. https://doi.org/10.1108/08876040610679954

[4] Babatunde, I.R., Iyanda, B.A, Mayowa, R.M. \& Ola, A.A. (2014). Journal of Sustainable Development in Africa 16(8).

[5] Bolton, B. \& Thompson, J. (2004). Entrepreneur: talent, temperament, technique.2nd ed. Oxford: Elsevier.

[6] Cant, M. 2003. Pricing management. South Africa: New Africa Books.

[7] Cassidy, K. \& Guilding, C. (2007). Tourist accommodation price setting in Australian strata titled properties. Hospitality management, 26:277-292.

[8] Collins, M. \& Parsa, H.G. (2006). Pricing strategies to maximize revenues in the lodging industry. Hospitality management, 25:91-107.

[9] Cooper, C., Fletcher, J., Fyall, A., Gilbert, D. \& Wanhill, S. (2008). Tourism Principles and Practice. Essex: Pearson Prentice Hall.

[10] Creswell, J.W. (2014). Research design qualitative, quantitative and mixed methods approaches. $4^{\text {th }}$ edition. Sage publications.

[11] Daramola, S.O. (2006). Research and statistical methods in education for students and researchers in tertiary institutions. Ilorin: Bamilex publishing. 
[12] Devashish, D. (2011). Tourism Marketing. India: Dorling Kindersley Pvt. Ltd

[13] De Keyers, R. \& Vanhove, N. (1994). The competitive situation of tourism in the Caribbean area: methodological approach. Tourism review, 49(3):19-22.

[14] Dwyer, L., Mellor, R., Livaic, Z., Edwards, D. \& Kim, C. (2004). Attributes of destination competitiveness: a factor analysis. Tourism analysis, 9(1):91-101.

[15] El-Nemr, N., Canel-Depitre, B. \& Taghipour, A. (2017). Determinants of hotel room rates. Marketing Trends Congress. Luxury Industries Conference London 2017, Sep 2017, Londre, United Kingdom. hal02332636

[16] Gomezelj, D.O. \& Mihalic, T. (2008). Destination competitiveness: applying different models, the case of Slovenia. Tourism management, 29:294-307.

[17] Haarhoff, R. 2007. An analysis of the price competitiveness of South Africa as an international tourist destination. Bloemfontein: Central University of Technology. (DTech Thesis).

[18] Hinterhuber, A. (2008). Customer value-based pricing strategies: why companies resist. Journal of Business Strategy, 125-134.

[19] Jennings, G. (2010). Tourism research. $2^{\text {nd }}$ ed. Sydney: John Wiley \& Sons Australia Limited.

[20] Jones, P. (2002). Introduction to Hospitality Operations: An Indispensable Guide to the Industry

[21] Keller, P. (1997). Tourism and environment: towards a new tourist culture. (Proceedings, Strasbourg (France), 21-23 November 1996. Published by Council of Europe. 62 p.)

[22] Koc, E. (2006). Total quality management and business excellence in services: the implications of allinclusive pricing system on internal and external customer satisfaction in the Turkish tourism market. Total quality management \& business excellence, 17(7):857-877.

[23] Kotler, P. (1988). Marketing Management: Analysis, Planning, Implementation and Control. 6th Ed. Englewood Cliffs, New Jersey. Prentice-Hall Inc.

[24] Lewis, R.C. \& Shoemaker, S. (1997). Price-sensitivity measurement: a tool for the hospitality industry. Cornell hotel and restaurant quarterly, 38(2):44-54.

[25] Lockyer, T. (2005). The perceived importance of price as one hotel selection dimension. Tourism management, 26:529-537.

[26] Lumsdon, L. (1997). Tourism marketing. London: International Thompson Press.

[27] Mangion, M., Durbarry, R. \& Sinclair, M.T. (2005). Tourism competitiveness: price and quality. Tourism economics, 11(1):45-68.

[28] Markgraf, B. (2015). Eight P's in Marketing Tourism. Texas: Hearst. McGraw-Hill.

[29] Middleton, F. (2019). The four types of validity. Available from: https://www.scribbr.com/methodology/ qualitative-quantitativeresearch/ [Accessed: 02/01/2020]

[30] Monroe, K.B. (2002). Pricing: making profitable decisions. 2nd ed. New York:

[31] Monty, B., \& Skidmore, M. (2003). Hedonic pricing and willingness to pay for bed and breakfast amenities in Southeast Wisconsin. Journal of Travel Research, 42: 195-199.

[32] Myers J. (2001), The Impact of Product Market Competition on Employment Determination in Unionized and Non-Unionized Firms: Firm Level Evidence for the U.K.", The Review of Industrial Organization, (4):385-394,

[33] Nassar, M., Yahaya, K.A. \& Shorun, C.Y. (2015). Total quality management and customer satisfaction in selected service industries in Ilorin, Nigeria. International Journal of Sustainable Development, 17(6): 145-162.

[34] Neuman, W.L. (2011). Social research methods qualitative and quantitive approaches. Pearson: Boston.

[35] O'Connor, P. (2002). An empirical analysis of hotel chain online pricing strategies. Information Technology \& Tourism, (5) 65-72

[36] Ruta, G. \& Pedroso, S. (2005). A tale of two tourism paradises: Puerto Plata and Punta Cana -the determinants of room price in the Dominican Republic using a hedonic function approach.

[37] Saayman, M. (2006). Marketing tourism products and destinations: getting back to the basics. $2^{\text {nd }}$ ed. Potchefstroom: Leisure Consultants and Publications.

[38] Shoemaker, S. (2003). The future of pricing in services. Journal of Revenue and Pricing Management, 271-279.

[39] Slabbert, E. \& Saayman, M. (2003). Guesthouse management in South Africa. $2^{\text {nd }}$ ed. Potchefstroom: Institute for Tourism and Leisure Studies. Potchefstroom: 
[40] Smith, G.E. \& Woodside, A.G. (2009). Pricing theory and practice in managing business-to-business brands. Advances in Business Marketing and Purchasing, (15) 429 - 486.

[41] Tefera, O. \& Govender, K. (2017). Service quality, customer satisfaction and loyalty: The perceptions of Ethiopian hotel guests. Journal of hospitality, tourism and leisure, 6(2).

[42] Varini, K., Engelmann, R., Claessen, B. \& Schleusener, M. (2003) Evaluation of the price-value perception of customers in Swiss hotels. Journal of Revenue \& Pricing Management, (2) 47-60.

[43] Wilson, A., Zeithaml, V.A., Bitner, M.J., \& Gremler, D.D. (2008). Services marketing: integrating customer focus across the firm. Glasgow: The Mcgraw-Hill Companies.

Citation: Dr Adediran Olabanji Jamiu, Alabi Risikat Abimbola. “Crucial Hoteliers and Guests' Perception on Factors Determining Pricing and Service Acceptability in Selected Hotels in Kwara State ". International Journal of Research in Tourism and Hospitality (IJRTH), vol 6, no. 1, 2020, pp. 35-50. doi: http://dx.doi.org/10.20431/2455-0043.0601004.

Copyright: (c) 2020 Authors. This is an open-access article distributed under the terms of the Creative Commons Attribution License, which permits unrestricted use, distribution, and reproduction in any medium, provided the original author and source are credited. 